\title{
FEASIBILITY STUDY OF THE Euphorbia pulcherrima PLANT EXTRACT AS NATURAL DYE WITH DIFFERENT MORDANTS FOR FABRIC DYEING
}

\author{
Netra Lal Bhandari ${ }^{* 1}$, Kabita Bist ${ }^{1}$, Jyoti Ghimire ${ }^{1}$, Santosh Chaudhary ${ }^{1,2}$, Durga Prasad Pandey ${ }^{2}$, Rameshwar $^{2}$ \\ Adhikari $^{2}$ \\ ${ }^{1}$ Department of Chemistry, Tri-Chandra Multiple Campus, Tribhuvan University, Kathmandu, Nepal \\ ${ }^{2}$ Research Centre for Applied Science and Technology (RECAST), Tribhuvan University, Kathmandu, Nepal \\ *Corresponding author: netra.tu.edu@gmail.com
}

(Received: August 11, 2019; Revised: December 23, 2019; Re-revised: May 22, 2020; Accepted: May 29, 2020)

\begin{abstract}
In the present study, an attempt has been made to utilize the natural plant dye extracted from petals of Euphorbia pulcherrima (locally called as Lalupate) via green techniques using water as solvent at boiling condition, for fabrics dyeing in combinations with natural mordants such as Aloe vera, Marcha (traditional yeast used in fermentation), and Chuk (traditional concentrated lemon juice), and artificial mordants like $\mathrm{K}_{2} \mathrm{Cr}_{2} \mathrm{O}_{7}, \mathrm{CuSO}_{4}$, and $\mathrm{FeSO}_{4}$. The dye extract has been characterized by thin-layer chromatography (TLC), ultraviolet-visible (UV-Vis) spectroscopy, Fourier transform infrared (FTIR) spectroscopy, gas chromatography-mass spectrometry (GC-MS) and optical microscopy (OM). The results have shown that the dyeing of the fabrics with the E. pulcherrima dye in combination with $\mathrm{K}_{2} \mathrm{Cr}_{2} \mathrm{O}_{7}$ as well as Chuk is effective concerning wash fastness, dry fastness, and colorfastness.
\end{abstract}

Keywords: Dyeing, Euphorbia pulcherrima, GC-MS, Mordants, Natural dyes

\section{INTRODUCTION}

The synthetic dyes are prone to release harmful chemicals that might be allergic and carcinogenic to human beings (Das et al., 2016). On the other hand, propelled by the ever-increasing awareness and concerns regarding the environmental protection (Jothi, 2008) the natural dyes obtained from different parts of plants are getting increased attention and their use in industries is evolving as a greener, safe and sustainable alternative (Nwonye \& Ezema, 2017; Patel 2011) in textiles, food, cosmetics, and pharmaceutical products. Beside safety issues, the minimal adverse environmental impacts, renewability from natural resources and, color pay-off are some of the advantages of natural dyes. Nevertheless, they have some disadvantages in terms of cost, ease of availability, color yield and varieties, limited shades, blending problems, and inadequate fastness (Adebayo et al., 2007; Ramprasath et al., 2017).

The natural dyes are generally more expensive than synthetic ones, due to their seasonal limitation in source materials availability. Their colors and pigments are variable as well, since depending on plant parts such as fruit, flower, seed, bark or leaves, the hues can vary. The uniformity can be difficult to achieve, in natural dyes as the ingredients- composition in particular plant materials may change from one season to another. This makes it challenging to standardize a recipe for natural dyes fabrication. The extraction of primary color and secondary color development depends on the plant material harvesting time, age and geographical distribution (Campbell, 2019). In particular, most of the disadvantages of natural dyes in textile dyeing can be overcome by using non-toxic and beneficial chemicals as mordants which produce an affinity between the fabric and the dye (Kulkarni et al., 2011) because the mordants enhance the chemical bonding of the natural dye with fibers (Samanta et al., 2018). However, all types of mordants of metal salts might not be considered as the bio-friendly (Banerjee et al. 2018) for dyeing of clothes.

In this regard, it is urgent to search for bio-friendly natural mordants and check their viability and sustainability for seeking to have better fastness properties against the toxic synthetic mordant of metal salts. Similarly, the natural dyes are color-fast with fibers; therefore, the use of mordant, which increases the dye fastness to the fabric is often necessary. A mordant is a fundamental material that is used for fixing natural dyes to the fibers, and it also improves the take-up quality, the color, and brightness of the fabric. The mordants are usually metallic salts of aluminum, chromium, iron, copper, and tin, as well as other natural products like tanning agents, wood ash, stale urine, acidic fruits extracts, and fungal products (Das et al., 2016; Kumar \& Prabha, 2018; Ramprasath et al., 2017).

Nepal has rich bio-diversity with about 182 indigenous dye yielding plants (Kunwar \& Bussmann, 2009) and the plant of Euphorbia pulcherrima (commonly known as poinsettia \& Lalupate in Nepali) is one of the widely distributed plants of Nepal including plants of Syangja district of Nepal. It is widely grown in the mid-hills of Nepal, and its uppermost red-colored leaves including flower parts were reported to be beneficial for dyeing many natural fibers like allo, cotton, jute, banana, sisal fibers, wool, and cotton clothes (Bhandari et al., 2019; 
Jothi, 2008; Malla, 1993; Rawat et al., 2005). Some previous research works are reported about the phytoconstituents (Joshi \& Bashyal, 2019; Sharma \& Kharel, 2019; Subba \& Thapa, 2018) and other aspects (Devkota, 2019) of many indigenous plants of Nepal. The phytochemical analysis of E. pulcherrima is scarcely reported and its uses as dye yielding plants is less studied (Malla, 1993). However, the ethanol extract of $E$. pulcherrima leaves was used to sensitized-ZnO photoelectrodes with an efficiency of 1.29 to $1.66 \%$ (Naresh Kumar et al., 2017, 2018; Silwal et al. 2019). Similarly, copper oxide nanoparticles were bio-synthesized from red leaves extract of E. pulcherrima plant that showed one of the promising materials for electrochemical energy storage applications (Sackey et al., 2020).

In this context, present work was aimed to study the viability, stability and sustainability of an aqueous extract of the uppermost red-colored leaves including flower parts of the E. pulcherrima plant for fabric dyeing purposes with and without the additions of different synthetic and natural (i.e., Chuk- concentrated black lemon juice, Aloe vera, and Marcha- a type of yeast used for fermentation) dye mordants. The aqueous extract of the plant has been characterized by various advanced analytical techniques.

\section{MATERIALS AND METHODS}

The uppermost red-colored leaves including the flower of the E. pulcherrima plant (Fig. 1) was collected from the local garden of Birgha village in Syangja district of Nepal, and it was authenticated as Euphorbia pulcherrima by the National Herbarium and Plant Laboratories, Godawari, Lalitpur, and its herbarium specimen was deposited at the Botany Department of Tri-Chandra Multiple Campus, Tribhuvan University, Kathmandu, Nepal.

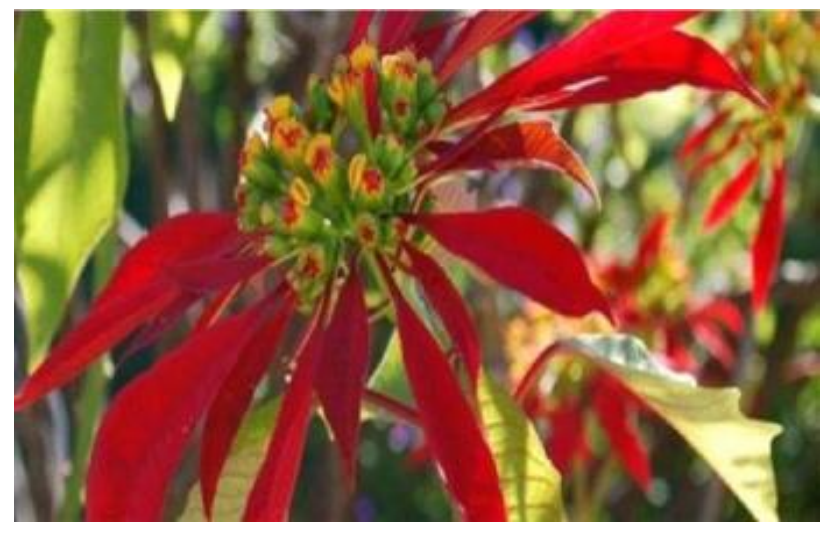

Fig. 1. Photograph showing the flowering part of Euphorbia pulcherrima used for dye extraction

The collected parts of the plant (uppermost red-colored leaves including the flower of E. pulcherrima) were rinsed with water, shade-dried, and ground to make powder. The $50 \mathrm{~g}$ of the powder was dissolved in $500 \mathrm{~mL}$ deionized water, left for 24 hours without frequent stirring, and then it was boiled for an hour in a hot water bath. The filtrate was evaporated at about $90{ }^{\circ} \mathrm{C}$ for 3 hours to convert it to paste of the dye which was further dried at $60{ }^{\circ} \mathrm{C}$ in an oven for 4 hours to obtain the powder form of the plant extract.

Eighteen pieces cotton knit fabrics of size $30 \mathrm{~cm}$ x $20 \mathrm{~cm}$ were used to test the dyeing ability of the plant extract. The effects of different natural mordants like concentrated black lemon juice, Aloe vera, and a type of yeast with the E. pulcherrima plant extract were studied. For comparative study, commercially available synthetic mordants of potassium dichromate, cupric sulfate, and ferrous sulfate were also used. Required numbers of the cotton fabrics were boiled with $\mathrm{Na}_{2} \mathrm{CO}_{3}$ solution for 20 minutes to remove the impurities, thoroughly washed with cold water, dried at room temperature, and transferred to mordant for 30 minutes followed by treatment in the plant extract dye bath for an hour. The effect of dye without mordant was also studied.

The E. pulcherrima plant extracts and the colored cotton fabrics were characterized using thin-layer chromatographic (TLC), column, chromatography, ultraviolet-visible (UV-Vis: ELICO Ltd., India, wavelength range of 200-800 nm) spectroscophic, Fourier transform infrared (FTIR: SHIMADZU, Japan using $\mathrm{KBr}$ pellets method, wavelength range of $500-4000 \mathrm{~cm}^{-1}$ ) spectroscopic, gas chromatograph-mass spectrometric (GC-MS), and optical microscopic (OM) techniques. About $1 \mathrm{~g}$ of the crude aqueous extract of E. pulcherrima with the 30:70 ratios of the ethanol and ethyl acetate solvents was loaded in a column having a $2.1 \mathrm{~cm}$ diameter for the column chromatographic analysis.

\section{RESULTS AND DISCUSSION}

The uppermost red-colored leaves including the flower of the E. pulcherrima plant yielded a dark reddish colored textile dye at initial screening. The five different mixed bands were identified from the TLC analysis of the $E$. pulcherrima plant extract as inserted in the table, and their retention factor $\left(\mathrm{R}_{\mathrm{f}}\right)$ values are tabulated in Table 1 . These results revealed that aqueous extract of the E. pulcherrima plant should constitute at least of five different active phyto-constituents.

Table 1. Different components with retention factor $\left(R_{f}\right)$ values of the $E$. pulcherrima plant extract dye

\begin{tabular}{lll}
\hline $\begin{array}{l}\text { Extract } \\
\text { components }\end{array}$ & $\mathbf{R}_{\mathbf{f}}$ & $\begin{array}{l}\text { TLC } \\
\text { analysis }\end{array}$ \\
\hline Components A & 0.08 & \\
Components B & 0.18 & \\
Components C & 0.37 & E \\
Components D & 0.45 & $5 \mathrm{C}$ \\
Components E & 0.70 & $8 \mathrm{~A}$ \\
\hline
\end{tabular}


Out of these five major active components observed in TLC in the crude extract of the E. pulcherrima, only four chromatograms (Fig. 2) corresponding to four different components were identified by the GC-MS analysis, and their retention time (RT) and \% peak area are summarized in Table 2. This result is in agreement with the fact that most of the natural dyes are a mixture of different color components rather than an individual color that might cause problems to fix the specific color shade during dyeing. These four chemical constituents were identified from the molecular mass and base peaks using a mass spectrometer connected to the gas chromatogram. The fragmentation patterns of each element were studied by the spectra, and the structure of each component was characterized (Table 2) by correlation with the spectra library of the National Forensic Science Laboratory (NFSL), Nepal.

The TLC and gas chromatogram showed red-colored band with $R_{f}$ value 0.45 (component $D$ ) as a major constituent in the crude aqueous extract extracted from the uppermost red-colored leaves including the flower of E. pulcherrima. The GC-chromatogram peak at the RT of 6.16 min with $85.3 \%$ area is the main peak, and was confirmed 1,2,3benzenetriol with a molecular ion peak at 126 in mass spectra (Table 2). The other components were found to be n-hexadecanoic acid, oleic acid, and benzoic acid-2,3,6trichloro-methyl ester and the relative abundance of these components was found to be $4.52 \%, 6.09 \%$, and $4.12 \%$, respectively. However, the present work mainly compared the color differences on fabric dyeing with crude dye and the red color band (the major component of extract) using natural and synthetic mordants.

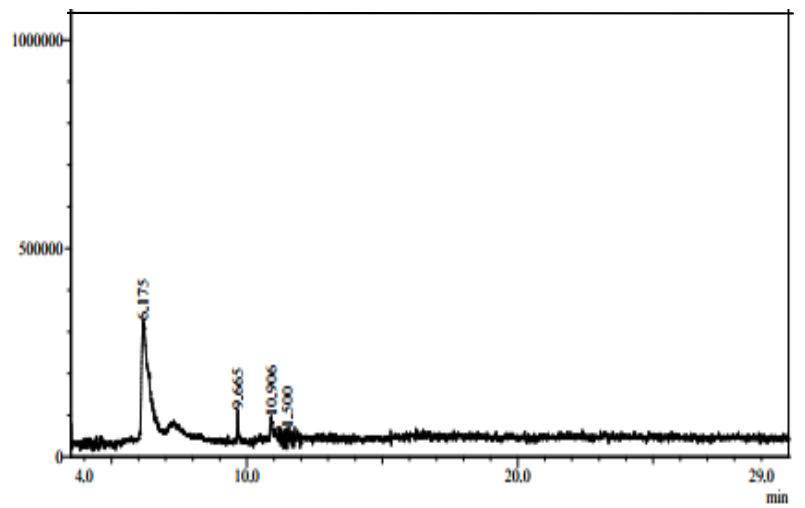

Fig. 2. Gas chromatogram (GC) showing the separation and analysis of crude dye extract of Euphorbia pulcherrima based on retention time (RT)

Table 2. Major phyto-constituents of dye extract in water from E. pulcherrima

\begin{tabular}{ccclccc}
\hline S. No. & RT (min.) & Area (\%) & Name of compound & Structure & Base peak & Mol. Mass \\
\hline $\mathbf{1}$ & $\mathbf{6 . 1 6}$ & $\mathbf{8 5 . 3}$ & $\mathbf{1 , 2 , 3 - B e n z e n e t r i o l}$ & $\mathbf{1 2 6}$ & $\mathbf{1 2 6}$ \\
2 & 9.67 & 4.5 & $\begin{array}{l}\text { n-Hexadecanoic acid } \\
3\end{array}$ & 10.91 & 6.1 & Oleic acid \\
4 & 11.50 & 4.1 & $\begin{array}{l}\text { Benzoic acid, } 2,3,6 \text { tri- } \\
\text { chloro-methyl ester }\end{array}$ & & 41.05 & 240 \\
& & & & &
\end{tabular}

Fig. 3 shows the FTIR spectra of the crude dye extract and the major component of E. pulcherrima. The peaks at $3408 \mathrm{~cm}^{-1}, 2926 \mathrm{~cm}^{-1}, 1605 \mathrm{~cm}^{-1}, 1420 \mathrm{~cm}^{-1}$, and $1060 \mathrm{~cm}^{-}$ 1 represent the $\mathrm{O}-\mathrm{H}$ stretching, $\mathrm{C}-\mathrm{H}$ stretching, $\mathrm{C}=\mathrm{O}$ stretching, aromatic $\mathrm{C}=\mathrm{C}$ stretching, and $\mathrm{C}-\mathrm{O}$ chelate ring, respectively. These FTIR spectra peak values are in agreement with the results reported for the Hibiscus rosasinensis and Euphorbia pulcherrima extracts (Adebayo et al., 2007, Ramprasath et al., 2017, Sackey et al., 2020). In a comparative FTIR analysis the redcolored band that was found to be the major active phytocomponent of the crude extract with a characteristic peaks of 1,2,3-benzenetriol as major constituent of GC-MS in Table 2 .

The UV-Vis spectrum of the crude extract of $E$. pulcherrima plant shows the absorption peaks at about $360 \mathrm{~nm}$ at $\mathrm{pH} 4$ and $\mathrm{pH} 9.2$, and about $430 \mathrm{~nm}$ at $\mathrm{pH} 13.2$, respectively, as shown in Fig. 4. A more intense UV-Vis peak at $430 \mathrm{~nm}$ in $\mathrm{pH} 13.2$ is attributed to the electronic transition of benzene and its derivatives, aromatic compounds such as anthocyanine and other ring compounds (Adebayo et al., 2007).

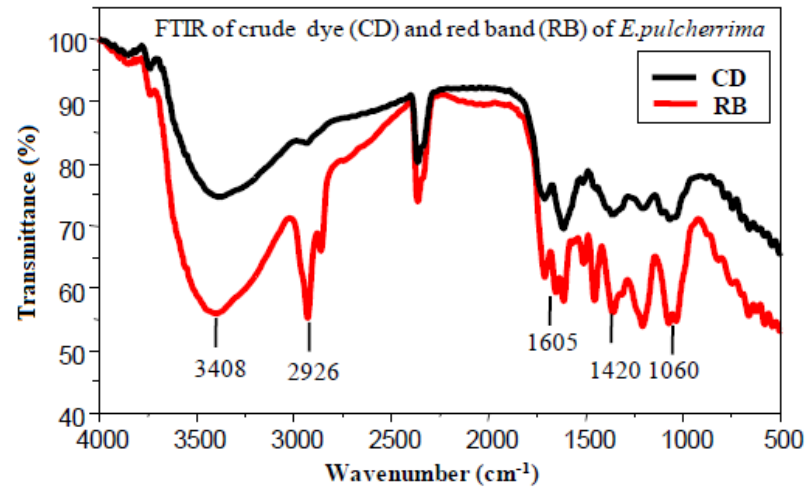

Fig. 3. FTIR spectra of crude dye (CD) of E. pulcherrima compared with the red band (RB) collected from column chromatography 


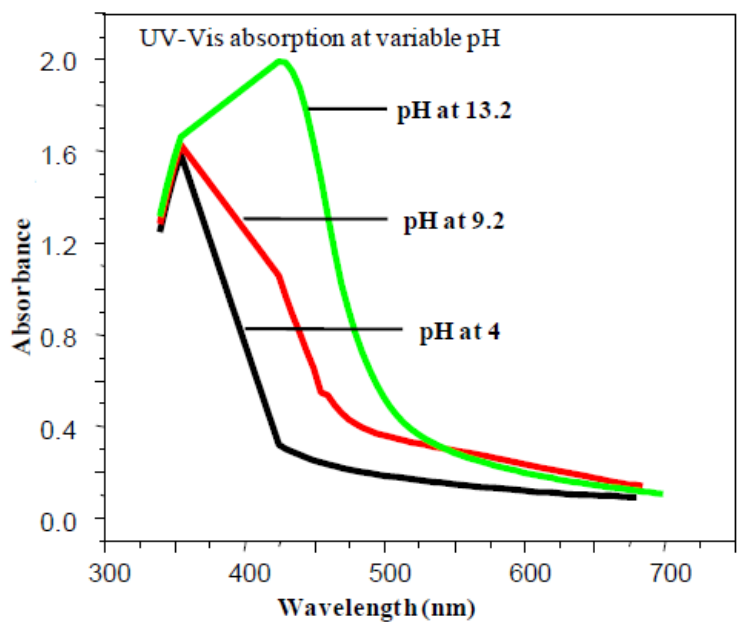

Fig. 4. Effect of pH on the UV-Vis absorption spectra of the dye extract

Consequently, it can be assumed that the increase in $\mathrm{pH}$ intensified the color of the cotton knit fabric dyeing due to the hyperchromic and bathochromic shifts of dye molecule by resonance.

Further, the effect of dye concentration with a fixed amount of natural mordant on Aloe-vera and concentrated black lemon juice was observed using on the UV-Vis absorbance spectra. The additions of $4,6,8$ and $10 \mathrm{~g} / \mathrm{L}$ aqueous solutions of E. pulcherrima plant extract on Aloevera $(10 \mathrm{~g} / \mathrm{L})$ result a bathochromic type shift from $420 \mathrm{~nm}$ to $424 \mathrm{~nm}, 530 \mathrm{~nm}$, and $460 \mathrm{~nm}$ wavelength, respectively, as shown in Fig. 5(a). Similar interesting results of the effect of Aloe-vera in silk dyeing was reported by Teklemedhin and Gopalakrishnan (2018), and they showed that at the concentration of $8 \mathrm{~g} / \mathrm{L}$ of dye solution containing $10 \mathrm{~g}$ of Aloe-vera illustrated the maximum bathochromic shift which would be ideal for the dyesensitized solar cells and dying fabrics.

In the case of the addition of concentrated black lemon juice, similar bathochromic wavelength shifting was observed, especially a sharp absorption peak at $465 \mathrm{~nm}$ wavelength with the addition of $8 \mathrm{~g} / \mathrm{L}$ dye concentration in mordant as illustrated in Fig. 5(b). No absorption peak was observed in the ultraviolet region without mordants in the aqueous solution only. The use of the concentrated black lemon juice as mordant not only showed the bathochromic shift but also intensified the absorption peak $\left(\chi_{\max }=465 \mathrm{~nm}\right)$ at a concentration of $8 \mathrm{~g} / \mathrm{L}$ of solution, and the idea was very informative to fix the dye while fabric dyeing and wash fastness. The use of Aloe-vera as a mordant showed better bathochromic shift $(\lambda \max =530$ $\mathrm{nm})$ compared to lemon juice $\left(\chi_{\max }=465 \mathrm{~nm}\right)$ and can be useful for the solar cells. These results revealed that the use of both natural mordants of Aloe-vera and concentrated black lemon juice enhanced equally the color intensity and light absorption towards the visible region in the UV-Vis spectrum and thus can replace the harmful synthetic mordants.
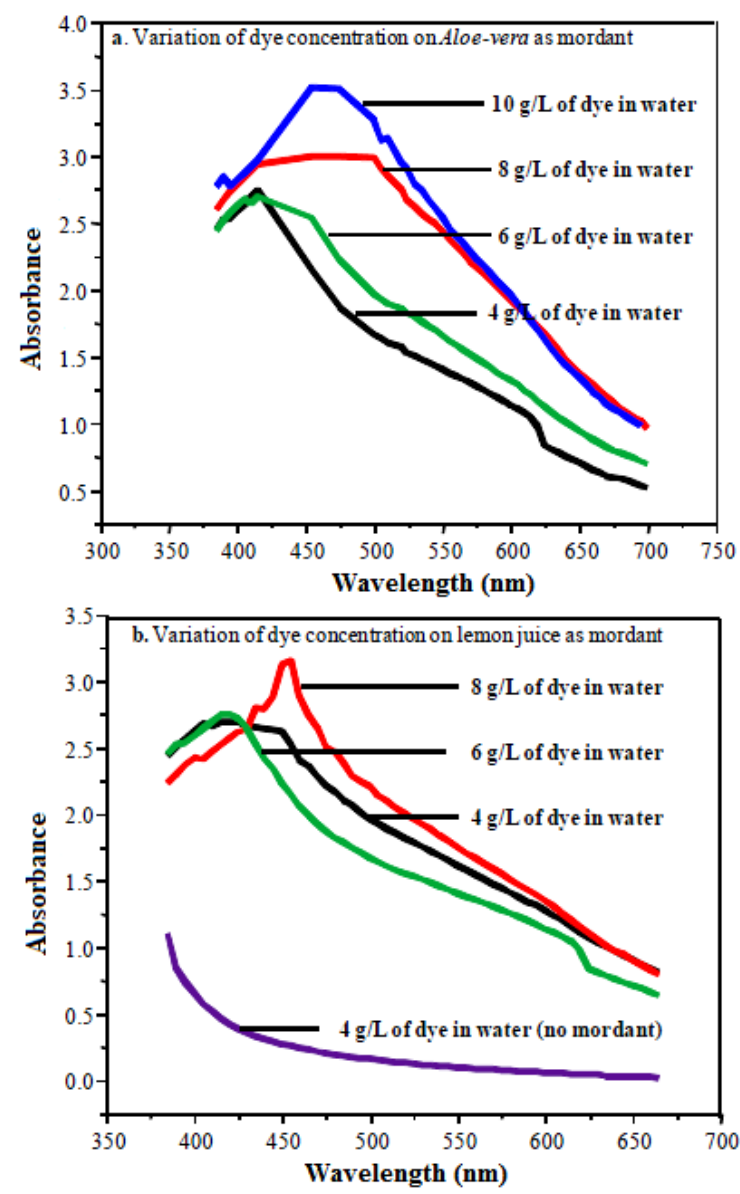

Fig. 5. Effect of different concentrations of dye extract on fixed amount of (a) Aloe-vera and (b) concentrated black lemon juice as natural mordant on the UV-Vis absorption spectra

\section{Fabrics dyeing}

The aqueous extract of E. pulcherrima in crude form and red-colored components obtained from the column were applied to different fabric dyeing, especially in cotton by using natural and synthetic mordants. Color shades developed by different mordants at different conditions are summarized in Table 3 using standard procedures as reported elsewhere (Adebayo et al., 2007; Kumar \& Prabha, 2018; Malla, 1993; Sackey et al., 2020). Other factors such as $\mathrm{pH}$, solvent, dye concentration, mordant concentration mordant variation that influence the color shade and wash fastness of dyeing colors and their optimization should be explored. A photograph of $E$. pulcherrima extracts color and the color developed on cotton cloth dyeing without mordants is shown in Fig. 6. Different color shades, obtained with varying mordants at various conditions in basic solutions are tabulated in Table 3. 
Table 3. Summary of dyeing and color developed with dye extract of E. pulcherrima with different mordants

\begin{tabular}{lccccccc}
\hline Mordants & $\begin{array}{c}\text { Amount } \\
(\mathbf{g})\end{array}$ & $\begin{array}{c}\text { Distilled } \\
\text { water }(\mathbf{m L})\end{array}$ & $\begin{array}{c}\text { Water } \\
\text { temp. }\left({ }^{\circ} \mathbf{C}\right)\end{array}$ & $\begin{array}{c}\text { Boiling } \\
\text { time }(\mathbf{m i n})\end{array}$ & $\begin{array}{c}\text { Mordanting } \\
\text { time }(\mathbf{m i n})\end{array}$ & $\begin{array}{c}\text { Mordanting } \\
\text { temp. }\left({ }^{\mathbf{C}}\right)\end{array}$ & $\begin{array}{c}\text { Color } \\
\text { obtained }\end{array}$ \\
\hline $\mathbf{K}_{\mathbf{2}} \mathbf{C r}_{2} \mathbf{O}_{7}$ & 0.05 & 50 & 60 & 60 & 30 & $30-40$ & Dark red \\
$\mathbf{F e S O}_{4}$ & 0.05 & 50 & 60 & 60 & 30 & $30-40$ & Dirty brown \\
$\mathbf{C u S O}_{4}$ & 0.05 & 50 & 60 & 60 & 30 & $30-40$ & Light green \\
Chuk & $2 \mathrm{~mL}$ & 50 & 100 & 60 & 30 & $40-50$ & Brown red \\
Marcha & $2 \mathrm{~mL}$ & 50 & 100 & 60 & 30 & $50-50$ & Light yellow \\
Aloe-vera & $2 \mathrm{~mL}$ & 50 & 100 & 60 & 30 & $40-50$ & Sharp red \\
\hline
\end{tabular}

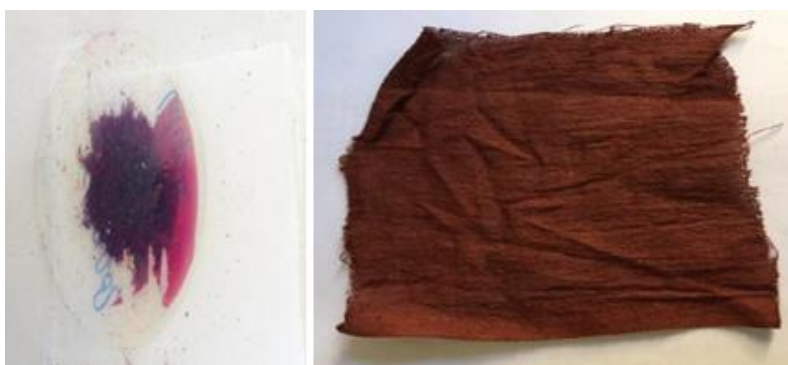

Fig. 6. Photographs of the crude dye of $E$. pulcherrima and dyeing on cotton fabric without mordant

For a comparative study, some representative optical photographs of different color shades developed by aqueous extract dye from E. pulcherrima plant after dyeing on cotton cloth by using natural and synthetic mordants at basic conditions ( $\mathrm{pH}$ range from 10-12) are shown in Fig. 7.

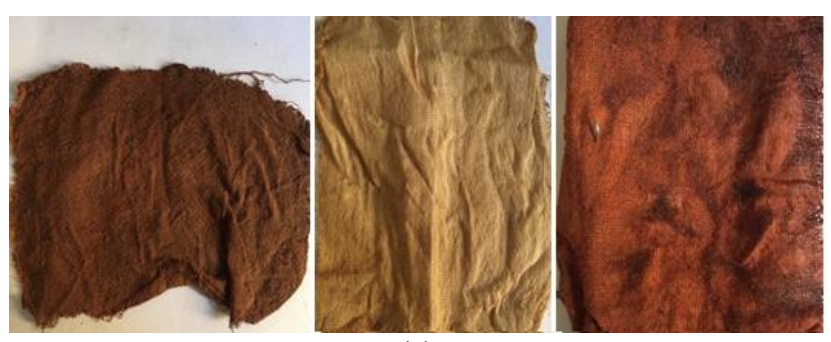

(a)

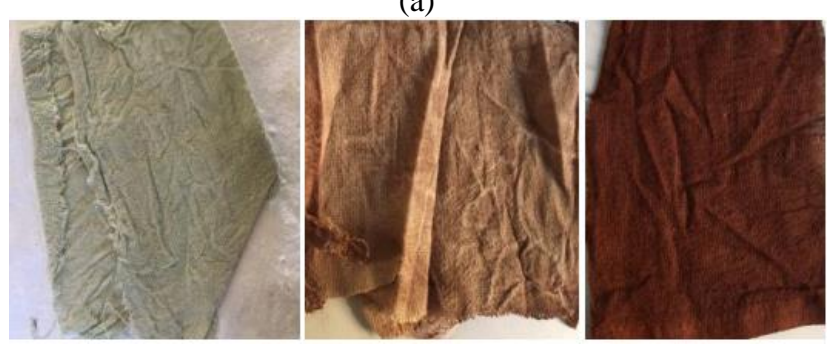

(b)

Fig. 7. Photographs showing cotton dyeing with (a) natural mordants; concentrated black lemon juice (Chuk), yeast used for fermentation (Mercha), and Aloe vera and (b) synthetic mordants; $\mathrm{CuSO}_{4}$, $\mathrm{FeSO}_{4}$, and $\mathrm{K}_{2} \mathrm{Cr}_{2} \mathrm{O}_{7}$ on crude dye of $E$. pulcherrima, respectively, from left to right
Among natural mordants used in this work, the Aloe vera, and concentrated black lemon juice were found to be better than a typical yeast for color, light, and wash fastness as illustrated in Fig. 7(a). Similar effects on natural mordants like vinegar and Aloe-vera (Kumar \& Malla, 2018; Teklemedhin \& Gopalakrishnan, 2018), and the synthetic mordants such as alum, $\mathrm{CuSO}_{4}, \mathrm{~K}_{2} \mathrm{Cr}_{2} \mathrm{O}_{7}$ (Ramprasath et al., 2017) on the dyes extracted from the marigold and Hibiscus rosasinensis plants were also reported in previous works.

Further, the color stability and wash fastness property of the natural mordant of the concentrated black lemon juice on the cotton fabric was found to be better among other natural mordants as shown in Fig. 8 but $\mathrm{K}_{2} \mathrm{Cr}_{2} \mathrm{O}_{7}$ was found to be even more improved than the concentrated black lemon juice. Although synthetic mordants are more effective (Fig. 8), the results of color development with natural mordants are encouraging. Despite low fixing capacity to cellulose fiber, natural mordants can produce a variety of shades but difficult to control and fix. It summarizes that cotton fabrics, on natural dyeing, the concentrated lemon juice (Chuk) shows better capacity of holding color gloom for longer time period among the different natural mordants used in experiment.

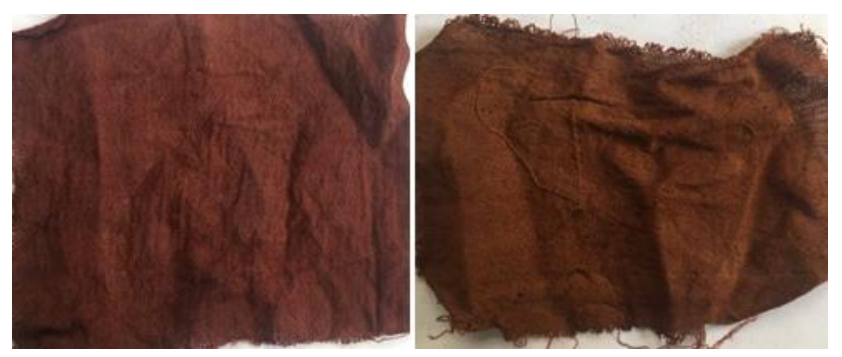

Fig. 8. Photographs showing a comparative colorfastness in cotton cloth dye from $E$. pulcherrima with $\mathrm{K}_{2} \mathrm{Cr}_{2} \mathrm{O}_{7}$ and the concentrated black lemon juice, respectively, after washing

\section{CONCLUSION}

The present study has explored the possibility of developing natural dyes from the easily available plants of 
Nepal and also selects the most suitable mordants. The aqueous extract of the uppermost red-colored leaves including the flower of the E. Pulcherrima plant was prepared and the physico-chemical properties of the dye as well as cotton fabrics dyed using the extract were investigated. The extract constituted mainly 1,2,3benzenetriol with the other three phyto-constituents as evidences by different chromatographic, spectroscopic, and GC-MS analyses. Among the natural mordants used in this study, the addition of the concentrated lemon juice is observed to be more stable for the gaining of color intensity, light fastness and wash fastness, whereas the Aloe-vera showed a long bathochromic shift towards the visible range compared to others.

The research outcome is expected to be useful in commercial purpose not only for the textile dyeing but also for foods, cosmetics, and pharmaceutical industries. In general, the fabric dyeing using a natural dye with natural mordants is quite challenging in controlling the color shade, color stability, and color duration as compared to the synthetic dyes and thus requires more investigations to make the techniques absolutely green.

\section{ACKNOWLEDGMENT}

Authors acknowledge the University Grants Commission (UGC-Nepal), Sanothimi, Bhaktapur for providing financial support as a UGC Small RDI Grants (Award No.: SRDIG-73/74-S\&T-09) in 2018 AD.

\section{REFERENCES}

Adebayo, G. B., Adekola, F. A., \& Olatunji, G. A. (2007). Chromatographic separation and spectro-analytical characterization of a nature African mineral dye. Chemical Society of Ethiopia, 21, 159-170.

Banerjee, A. N., Kotnala, O. P., \& Maulik, S. R. (2018). Dyeing of Eri Silk with natural dyes in presence of natural mordants. Indian Journal of Traditional Knowledge, 17, 396-399.

Bhandari, N. L., Dhungana, B. R., Lach, R., Henning, S., \& Adhikari, R. (2019). Synthesis and characterization of urea-formaldehyde eco-friendly composite based on natural fibers. Journal of Institute of Science and Technology, 24(1), 19-25.

Campbell, U. (2019). The importance of natural dyes. https://biofriendlyplanet.com/greenalternatives/natural/the-importance-of-natural-dyes/ (retrieved on May 1, 2020)

Das, M. P., Priyanka, R., Zaibunisa, A. M., \& Sivagami, K. (2016). Eco-safe textile coloration using natural dye. International Journal of Pharmaceutical Sciences Review and Research, 39, 163-166.
Devkota, M. (2019). Canopy research in Nepal Himalayas: Opportunities and challenges. Journal of Institute of Science and Technology, 24(2), 1-6.

Joshi, S., \& Bashyal, S. (2019). Study on the chemical constituents and antibacterial activity of essential oil of Acarus calamus L. rhizomes of Rupendehi district (Nepal). Journal of Institute of Science and Technology, 23(1), 57-60.

Jothi, D. (2008). Extraction of natural dyes from African marigold flower (Tagetes erectal) for textile coloration. AUTEX Research Journal, 8, 49-52.

Kulkarni, S. S., Gokhale, A. V., Bodake, U. M., \& Pathade, G. R. (2011). Cotton dyeing with natural dye extracted from pomegranate (Punica granatum) peel. Universal Journal of Environmental Research \& Technology, 1, 135-139.

Kumar, N. P., Sakthivel, K., \& Balasubramanian, V. (2017). Microwave-assisted biosynthesis of riceshaped $\mathrm{ZnO}$ nanoparticles using Amorphophallus konjac tuber extract and its application in dyesensitized solar cells. Materials Science-Poland, 35(1), 111-119.

Kumar, N. P., Sakthivel, K., Balasubramanian, V., Sengottaiyan, D., \& Duresh, J. (2018). Microwaveassisted green synthesis of $\mathrm{ZnO}$ nanorods for dyesensitized solar cell application. Indian Journal of Chemical Technology, 25(4), 383-389.

Kumar, V., \& Prabha, R. (2018). Extraction and analysis of natural dye. Journal of Natural Product and Plant Resources, 8, 32-38.

Kunwar, R., \& Bussmann, R. (2009). Medicinal, aromatic \& dye plants of Baitadi \& Darchula districts. Nepal Himalaya: Status, Uses \& Management, 3, 43-49.

Malla, L. (1993). The Natural Dyes of Nepal. A research report submitted to the Research Center for Applied Science and Technology (RECAST), Tribhuvan University, Nepal, p. 142.

Nwonye, N. U., \& Ezema, P. N. (2017). Extraction and utilization of natural dye extract from corn leaf. International Journal of Development Strategies in Humanities, Management \& Social Sciences,7, 4051.

Patel, N. K. (2011). Natural dye-based Sindoor. Life Sciences Leaflets, 11, 355-361.

Ramprasath, R., Kavi, G. G., \& Rathi, S. T. (2017). Isolation of natural dyes from Hibiscus rosasinensis and marigold flower and dye properties of the dye on cotton cloth. IOSR Journal of Applied Chemistry (IOSR-JAC), 10, 74-79. 
Rawat, B., Jahan, S., Sharma, E., \& Yadav, S. (2005). Colorfastness properties of silk fabric dyed with poinsettia leaves. Asian Textile Journal, 48, 418420 .

Sackey, J., Nwanya, A. C., Bashir, A. K. H., Matinise, N., Ngilirabanga, J. B., Ameh, A. E., Coetsee, E., \& Maaza, M. (2020). Electrochemical properties of Euphorbia pulcherrima mediated copper oxide nanoparticles. Materials Chemistry and Physics, 244, 122714.

Samanta, P., Singhee, P., \& Samanta, A.K. (2018). Fundamentals of natural dyeing of textiles: Pros and cons. Current Trends of Fashion Technology \& Textile Engineering, 2(4), 555593.

Sharma, K., \& Kharel, R. (2019). Antibacterial, antidiabetic, and brine shrimp lethality activities of some selected medicinal plants from Kavrepalanchok district of Nepal. Journal of Institute of Science and Technology, 24(1), 57-62.

Silwal, S. B., Adhikari, R., Lamichhane, P., \& Bhandari, N. L. (2020). Natural dyes as photo-sensitizer in solar cells. Bibechana, 17, 28-33.

Subba, B., \& Thapa, S. (2018). Analysis of phytoconstituents and biological activities on the selected medicinal plants of Dolakha and Sindhualchowk district of Nepal. Journal of Institute of Science and Technology, 22(2), 140-147.

Teklemedhin, T. B. \& Gopalakrishnan, L. H. (2018). Environmental friendly dyeing of silk fabric with natural dye extracted from Cassia singueana plant. Journal of Textile Science \& Engineering, S3, 001. DOI:10.4172/2165-8064.S3-001. 